\title{
Exploration of Innovation and Entrepreneurship Education for Higher Vocational College Student on Basis of Overall Talent Training Process
}

\author{
Yue Zhang, Jinghui Zhao, Xiaodan Jia \\ Liaoning Mechatronics College, Dandong Liaoning, 118009, China
}

\begin{abstract}
Keywords: Talent Training, Higher Vocational College Students, Innovation and Entrepreneurship, Education, Exploration
\end{abstract}

\begin{abstract}
Innovation and entrepreneurship education belongs to a kind of new idea in the entrepreneurship cultivation process of higher vocational college students, exerting a great effect on students innovation, creation and entrepreneurship. On this basis, this paper takes the overall talent training process as basic perspective and explores the innovation and entrepreneurship education for higher vocational college
\end{abstract}

\section{Introduction}

Higher vocational college students are the technical talented person whom the education department has cultivated for our country. Although certain progress has been achieved in the entrepreneurship process, problems like obscure concept consciousness, incomplete talent training patterns, etc are still exiting. Therefore, the following parts serve as the exploration of innovation and entrepreneurship education for higher vocational college students.

\section{Understanding of innovation and entrepreneurship education}

"Innovation and entrepreneurship education" under conditions of the new period mainly refers to innovation education, entrepreneurship education and student education which have been integrated together. With the influence of this teaching model, more attention has been paid to students entrepreneurial practice with theoretical basis, making students have relatively more sufficient understanding of their own learning situations and life path, and form a kind of self image in learning process. Only in this way can students have more sincere entrepreneur spirit and sufficient innovation spirit, excavate their own potential, and form innovation and entrepreneurship ability. The process of innovation and entrepreneurship education for higher vocational college students not only creates an employment route for students but also cultivates talents for country and society. Therefore it can deal with the changeable world economy situation. At the same time, it is also a way of improving educational quality and perfecting educational approach.

"Innovation and entrepreneurship education" refers to the education of students entrepreneurship, organically integrates innovation and entrepreneurship together, carries out systematic training for students, and adds talent training and entrepreneurship contents to students professional course teaching and practice process.

\section{Necessity analysis on innovation and entrepreneurship education system construction of higher vocational college students}

With the rapid development of economy, science and technology in new period, our country should pay attention to training of innovative talents and increase input of innovation in order to break the international competitive barriers. Only in this way can the future of our country have synchronous development of talents and economy. Under such kind of situation, plenty of innovation and entrepreneurship talents should be trained so that the effective knowledge power can be turned to economic power and the target of synergetic development can be achieved. At the same time, students in Chinese common colleges and higher vocational colleges are gradually increasing every year, which increases students employment pressure and makes employment situation even more 
serious. Under so intense competitive employment environment, higher vocational college students should have innovative presentation except for comprehensive quality and knowledge storage. On this basis, the students can cope with the intense employment situation. Higher vocational colleges adopt proper methods to provide innovation and entrepreneurship education for students, which will have more practical significance. In addition, the increasingly prominent development of economic globalization and knowledge globalization serves as the best opportunity for our country to become a great power and construct innovative country. The government also introduces some preferential policy in the aspect of constructing an innovative country, which is very favorable for students entrepreneurship. Higher vocational colleges with this educational idea should energetically construct such kind of educational system in order to promote their teaching level ${ }^{[1]}$.

\section{Researches on innovation and entrepreneurship education development situation in perspective of overall talent training process}

\section{Positioning problem of innovation and entrepreneurship education in perspective of overall talent training process}

Under the background of new period, many higher vocational colleges do not have a correct understanding of college students innovation and entrepreneurship education. Therefore, the idea and positioning are obscure. As for the educational idea of college students, it is generally considered that entrepreneurship is the concept of future entrepreneur. This wrong educational idea exerts a great influence on students correct understanding of entrepreneurship, which also goes against the countrys original idea of advocating college students to receive entrepreneurship education. In such kind of awareness, insufficient attention has been paid to students innovative ability and potential training, so the educational management is out of question. Some educators once discussed this problem in 2013. Until now, many higher vocational colleges still have no clear positioning of innovation and entrepreneurship education. People with entrepreneurship will become entrepreneurs. It is a one-sided opinion, because entrepreneurship can only enable a few people to become entrepreneurs, which does not show that innovation and entrepreneurship education only serves for those few people. Teachers practical activities on theoretical basis should train students entrepreneurship awareness and entrepreneurship interest in various ways. In addition, students should have a relatively in-depth understanding of entrepreneurship through long-term observation. Therefore, teachers can grasp students entrepreneurship orientation and then correct the previous deflected understanding innovation and entrepreneurship education ${ }^{[2]}$.

\section{Second classroom effects on innovation and entrepreneurship education in perspective of overall talent training process}

Some higher vocational colleges pay more attention to the practical operation of students entrepreneurship based on the talent ability demands of times. Such kind of educational idea is correct and suitable for the social demands, making sufficient preparation for students employment in the future. However, some basic problems still exist. For example, some majors in colleges carry out entrepreneurship practice in the process when students do not learn theoretical knowledge very well. Students lack understanding of entrepreneurship projects and theoretical guidance. Some students learn certain theoretical knowledge, but the contents are plain and basically some separated courses of non-majors. Therefore this inconsiderate method brings about serious disconnection of entrepreneurship practice and theoretical study of higher vocational college students. A kind of concept has formed in students mind. That is to say, innovation and entrepreneurship education refers to the grasp of professional operation and technique rather than too much theoretical knowledge. Nevertheless, college students are concerned with extensive knowledge which is not confined to their own majors in entrepreneurship process. Therefore, the combination of theory and practice must be realized. If the attention has been paid to merely practice, deficiencies will occur in students entrepreneurship quality and problems will emerge one after another in the following entrepreneurship process. 


\section{Innovation and entrepreneurship education theory overweights practice in perspective of overall talent training process}

It has been mention above that some higher vocational colleges pay too much attention to the practice of innovation and entrepreneurship education but neglect theoretical research, which actually causes disconnection of reality and theory. However, some colleges and universities are exactly the opposite. Although they have conducted some entrepreneurship theory education, made entrepreneurship reports, and invited outstanding entrepreneurship schoolfellows to give speech, they still lack the promotion of students comprehensive quality education and sufficient practical chances. After listening speech and report, students passion will gradually fade away and their entrepreneurship attempt will also gradually disappear. Some students have strong desire for entrepreneurship, hoping that they can create a future on basis of their own ability. Without practice, the temporary passion can not exert a substantial influence on entrepreneurship education. Therefore, higher vocational colleges carry out innovation and entrepreneurship education to make students take part in entrepreneurship practice process after deep-seated theoretical learning and comprehensive stimuli, avoiding innovation and entrepreneurship education from staying on the surface ${ }^{[3]}$.

\section{Insufficient popularity and benefit area of innovation and entrepreneurship education in perspective of overall talent training process}

Many higher vocational colleges take the overall talent training process as basic starting point to carry out innovation and entrepreneurship education. Under such kind of educational pattern, some students have achieved comprehensive entrepreneurship quality promotion, and gained certain achievement in entrepreneurship process, but such kind of group in college students is rather limited. Plenty of entrepreneurship education in China takes entrepreneurship competition as basic point, but students who take part in the competition are limited. Many students merely play the role of spectators and do not have personal feeling in competition and practice as well as in-depth understanding of entrepreneurship.

\section{Teaching contents and approaches of innovation and entrepreneurship education remain to be improved in perspective of overall talent training process}

In other countries, education in no matter higher vocational colleges or general colleges starts to pay attention to innovation and entrepreneurship, so teaching approach in this aspect has been improved and textbook in this aspect is also prepared. In China, although this course is opened in many colleges and universities, it merely refers to the teaching of theoretical knowledge. No unified and normative teaching system has been formed, let alone perfected education and teaching programme. Teachers in teaching process can only educate students out of their own understanding, so their teaching contents are quite different and students promotion is limited. To put it simply, this course in higher vocational colleges is still formalized.

\section{Strategy researches on higher vocational innovation and entrepreneurship education in perspective of overall talent training process}

\section{Construction of innovation and entrepreneurship education system in higher vocational colleges}

In other words, innovation and entrepreneurship education is a kind of diversified challenge no matter for students or the higher vocational colleges. Colleges in teaching process should focus mostly on the practical talents who have innovative ability and entrepreneurship skill, encourage them to carry out entrepreneurship, and reduce the talent loss in entrepreneurship process. Different methods should be adopted for the entrepreneurship education of various groups. Therefore, higher vocational colleges should change traditional education and teaching idea. Building perfected innovation and entrepreneurship education system will greatly promote the higher vocational colleges cultivation intensity of innovation and entrepreneurship talents, and help them to conduct entrepreneurship after graduation. Besides, colleges and universities can make full use of on-campus 
and off-campus resources, apply these recourses to innovation and entrepreneurship education system, and push forward the cultivation of innovation and entrepreneurship talents ${ }^{[4]}$.

Higher vocational colleges train advanced talents for our country. Therefore, both their educational idea and educational approach should keep up with the times. On the one hand, higher vocational colleges should fully understand that innovation and entrepreneurship education can ease the intense employment situation of college students. Students entrepreneurship practical ability should be constantly improved in teaching. They should also realize that they will face so many difficulties in entrepreneurship process and know how to deal with them. At the same time, higher vocational colleges realize that innovation and entrepreneurship education plays a vital role in long-term development of colleges, so they should constantly cultivate new talents and broaden students road.

\section{Construction of college students innovation and entrepreneurship simulative practice platform}

Firstly, a simulative entrepreneurship practical platform should be built for students. Higher vocational colleges build simulative entrepreneurship practical platform in innovation and entrepreneurship education, aiming to integrate students theoretical knowledge and practice together and carry forward the promotion of students entrepreneurship quality. Colleges should make full use of their own experimental teaching conditions like carrying out practical training of ERP enterprise operation and management, constructing simulative entrepreneurship class, etc. Modern Internet technology should used to purchase some standard entrepreneurship practice software, build a simulative entrepreneurship practical platform for students, and offer students entrepreneurship practical training chances at any time. In addition, colleges can also encourage students to hold entrepreneurship and marketing planning competitions, economical situation evaluation competitions, accounting skill competitions, etc, constantly enriching students learning of the second class in innovation and entrepreneurship education and constantly improving students entrepreneurship feeling and skills.

Secondly, comprehensive entrepreneurship practical platform should be built. In higher vocational colleges, building comprehensive entrepreneurship practical platform is favorable for students real experience of entrepreneurship, which is also the major objective of innovation and entrepreneurship education in colleges and universities as well as the sole standard for teaching result verification. On the one hand, students in this process should participate in more challengeable competitions. On the other hand, colleges advantages should be used to provide entrepreneurship positions for students, and take responsibility of their own profit and loss with reference of enterprises operation and management pattern. Colleges can offer capital support and loan in accordance with students actual situation and demands ${ }^{[5]}$.

\section{Construction of reinforcing the course contents of innovation and entrepreneurship education}

Construction of entrepreneurship contents mainly starts from the basic courses of innovation and entrepreneurship. Colleges should reinforce the training of knowledge, ability and quality in accordance with students existing ability. Periodical pattern can be adopted in the setting of courses. For example, students in the first year can learn entrepreneurship theoretical courses and have an initial understanding of entrepreneurship. Students in the second year should communicate more with others and learn more for preparation of entrepreneurship phase. Students in third year should have entrepreneurship practice and brand-new understanding of innovation and entrepreneurship at various phases.

\section{Determining students dominant position in innovation and entrepreneurship education of higher vocational colleges}

Students dominant role in innovation and entrepreneurship education mainly emphasizes students subject position in classroom learning and practice. Teachers can set different entrepreneurship learning targets for students in various grades, accomplish the targets through students learning or cooperation, and enable students to correctly position their own future, keep mental and physical 
health, and maintain passion and confident for entrepreneurship, setting solid foundation for students entrepreneurship in the future.

Construction of innovation and entrepreneurship education teaching staff in higher vocational

\section{colleges}

Teachers quality is closely linked with students learning performance. Therefore, teaching staffs quality construction should be comprehensively reinforced in process of carrying out innovation and entrepreneurship education practice. Teachers with prominent performance should be encouraged. Some young teachers with insufficient experience should usually take part in some enterprise training activities in order to grasp advanced ideas and guide students to achieve more prominent progress in educational process.

\section{Conclusion}

In conclusion, this paper analyzes the innovation and entrepreneurship education in higher vocational colleges on basis of overall talent training process, and puts forward current existing problems and countermeasures, hoping to provide assistance for innovation and entrepreneurship education courses in colleges and universities.

\section{Acknowledgement}

This paper belongs to the 2015 programmed research projects of Modern Vocational Education Institute with the project name as Innovation and Entrepreneurship Research and Practice for Higher Vocational College Students. It is also the 2016 Liaoning economic and social development project with the project name as Liaoning Internet in Colleges and Universities + Innovation and Entrepreneurship Theoretical Research and Practice and the number as 2016lslktzijyx-08.

\section{References}

[1] Li Pingyuan. Thoughts on integrating innovation and entrepreneurship education into overall talent training process. Journal of Innovation and Enterprise Education, 2013,36(4):31-33.

[2] Ji Xinhao. Study on innovation and entrepreneurship education for higher vocational college students on basis of overall talent training process. Adult Education, 2014,34(9):68-70.

[3] Ji Xinhao. Study on innovation and entrepreneurship education for higher vocational college students on basis of overall talent training process. Chinese Market, 2012,22(27):113-114.

[4] Video conference for integrating innovation and entrepreneurship education into overall talent training process and deepening innovation and entrepreneurship education reform in colleges and universities. China University Students Career Guide (Integrated Science), 2015,14(7):456-477

[5] Cheng Xiangyang. Integrating practical teaching into overall talent training process: practice and characteristic of talent training quality in College of Information Engineering in Fuyang Normal University.Journal of Fuyang Normal University (Social Science Edition), 2012,18(5):135-137. 